\title{
Oxygen Free-Radical Reduction of Brain Capillary Rubidium Uptake
}

\author{
Warren D. Lo and A. Lorris Betz \\ Departments of Pediatrics and Neurology, University of Michigan, Ann Arbor, Michigan, U.S.A.
}

\begin{abstract}
Free radicals are proposed to play a role in the injury following cerebral ischemia in which cerebral edema is a prominent feature. To determine whether free radicals might alter the movement of ions and water across the blood-brain barrier, we examined their effect on brain capillary transport. Rat brain capillaries were isolated, incubated with a system that generates free radicals, and various capillary transport systems were studied. Rubidium uptake was reduced $74 \%$ whereas rubidium efflux, glucose transport, and capillary water space were unchanged. The results following the addition
\end{abstract}

of radical scavengers indicated that hydrogen peroxide or a related free radical was the toxic species. These data suggest that free radicals can impair capillary endothelial cell mechanisms that help maintain homeostasis of electrolytes and water in brain. Key Words: Free radicals Brain capillaries-Cerebral ischemia- $\mathrm{Na}^{+}, \mathrm{K}^{+}-$ ATPase-Blood-brain barrier-Rubidium transport. Lo W. D. and Betz A. L. Oxygen free-radical reduction of brain capillary rubidium uptake. $J$. Neurochem. 46, 394398 (1986).
Free radicals are proposed as mediators of tissue injury, in response to diverse insults such as ischemia, radiation, oxygen toxicity, and aging (Miquel et al., 1977; Adams and Wardman, 1977; Fridovich, 1978; Del Maestro, 1980). In brain, free radicals appear to be produced during cerebral ischemia and reperfusion (Yamamoto et al., 1983; Watson et al., 1984); however, their role in the mediation or augmentation of ischemic brain damage has not been firmly established. One group of investigators reported that within hours after a free radical generating system was injected into cerebral parenchyma, cell necrosis, cerebral edema, and increased vascular permeability to Evans Blue dye were detected (Chan et al., 1983, 1984).

The brain capillary endothelial cell plays an important role in maintaining brain ion homeostasis (Bradbury, 1979; Goldstein and Betz, 1983). This cell may be particularly susceptible to attack by free radicals since brain capillaries are enriched in xanthine oxidase which, with a suitable substrate, will form free radicals (Betz, 1985). During cerebral ischemia it is possible brain endothelial cells produce free radicals that subsequently damage endo- thelial cell water and ion homeostatic mechanisms and exacerbate the changes in $\mathrm{Na}, \mathrm{K}$, and water seen in cytotoxic brain edema. To test a part of this proposed mechanism, we examined the effects of free radical species on transport properties of isolated brain capillaries.

\section{MATERIALS AND METHODS}

Male Sprague-Dawley rats were obtained from Harlan (Haslett, MI, U.S.A.). ${ }^{86}$ Rubidium chloride, sp act $0.5-$ $35 \mathrm{Ci} / \mathrm{g}\left({ }^{86} \mathrm{Rb}\right) ; \alpha-\left[1-{ }^{14} \mathrm{C}\right]$ methylaminoisobutyric acid, sp act $48.4 \mathrm{mCi} / \mathrm{mmol}\left(\left[{ }^{14} \mathrm{C}\right] \mathrm{meAlB}\right)$; and methyl-D-glucose, $3-O-\left[\right.$ methyl $\left.-{ }^{3} \mathrm{H}\right]$, sp act $79 \mathrm{Ci} / \mathrm{mmol}\left(\left[{ }^{3} \mathrm{H}\right] 3-O-\mathrm{MG}\right)$ were purchased from New England Nuclear (Boston, MA, U.S.A.). Acetaldehyde was obtained from Mallinkrodt (St. Louis, MO, U.S.A.). All other reagents, including xanthine oxidase type I, were purchased from Sigma (St. Louis, MO, U.S.A.).

\section{Isolation of brain microvessels}

Brain capillaries were prepared by homogenization, dextran gradient centrifugation, and glass bead filtration as previously described (Betz, 1983). The capillary pellet was then suspended in Dulbecco's phosphate-buffered saline with $1 \mathrm{mM} \mathrm{CaCl}, 5 \mathrm{mM}$ glucose, and $1 \%$ bovine
Received February 20, 1985; accepted July 29, 1985.

Address correspondence and reprint requests to Dr. A. L. Betz at Departments of Pediatrics and Neurology, University of Michigan, Ann Arbor, MI 48109, U.S.A.
Abbreviations used: HEPES, $N$-2-hydroxyethylpiperazine- $N^{\prime}$ 2-ethanesulfonic acid; meAIB, $\alpha$-methylaminoisobutyric acid; 3 $O$-MG, 3-O-methyl-D-glucose; PBS, phosphate-buffered saline. 
serum albumin (PBS). The suspension was kept on ice until use within $3 \mathrm{~h}$ of isolation. Aliquots for capillary protein content were washed free of albumin, dissolved in $0.5 \mathrm{M} \mathrm{NaOH}$, and then protein was determined by the Biorad protein assay (Biorad Labs, Richmond, CA, U.S.A.).

\section{Free radical generation}

The commercially available xanthine oxidase suspension was dialyzed for $4 \mathrm{~h}$ against 1,000 volumes of PBS at $4^{\circ} \mathrm{C}$, diluted in PBS to the desired concentration, and kept on ice. Substrates, inhibitors, and free radical scavengers were added just prior to use. Superoxide anion production was qualitatively assessed using the reduction of nitroblue tetrazolium to nitroforman by the superoxide anion. This reaction appeared equally effective with either hypoxanthine or acetaldehyde as substrates for xanthine oxidase. Acetaldehyde was glass-distilled prior to each experiment, and was kept in a glass-stoppered bottle at $4^{\circ} \mathrm{C}$.

\section{Uptake studies}

A $0.1-\mathrm{ml}$ aliquot of the xanthine oxidase suspension and a $0.1-\mathrm{ml}$ aliquot of the capillary suspension were combined and preincubated at $37^{\circ} \mathrm{C}$ for various times. ${ }^{86} \mathrm{Rb}$ uptake was measured by addition of $0.05 \mathrm{ml}$ of the isotope in PBS to the reaction mixture and then incubation of the suspension at $37^{\circ} \mathrm{C}$ for predetermined times. Uptake was terminated by trapping the capillaries on a nitrocellulose filter $(1.2 \mu \mathrm{m}$ pore size) and washing with an iced stop solution. For experiments with ${ }^{86} \mathrm{Rb}$, the filters were prewashed with $1 \mathrm{M} \mathrm{KCl}$. The stop solution consisted of $10 \mathrm{~m} M N$-2-hydroxyethylpiperazine- $N^{\prime}-2$ ethanesulfonic acid (HEPES)-buffered saline, $\mathrm{pH} 7.4$. Glucose uptake was measured by using $\left[{ }^{3} \mathrm{H}\right] 3-O-M G$ in Dulbecco's PBS with $1 \mathrm{mMCaCl}, 1 \%$ bovine serum albumin, $5 \mathrm{~m} M$ pyruvate, and $5 \mathrm{mM}$ unlabeled 3-O-MG. The capillary suspension was then incubated at $37^{\circ} \mathrm{C}$ for $30 \mathrm{~s}$ for glucose transport studies or $10 \mathrm{~min}$ for glucoseequilibrium distribution studies. The wash solution consisted of ice-cold HEPES-buffered saline with $10 \mu M$ cytochalasin $B$ added to reduce the loss of label during the wash procedure. L-Amino acid uptake was measured using $\left[{ }^{14} \mathrm{C}\right] \mathrm{me} A I B$ in the presence of $1 \mathrm{~m} M$ unlabeled meAIB as a carrier.

Capillaries trapped on filters were lysed with $0.5 \mathrm{ml}$ distilled water and mixed with Safety-Solve scintillation fluid (RPI, Mount Prospect, IL, U.S.A.). Counting was performed using a Beckman LS-7500 scintillation counter. The cpm per sample was divided by the cpm of a known volume of isotope and then divided by the amount of protein per sample. Uptake of isotope was then expressed as the equivalent of radioisotope-containing incubation media taken up per milligram of capillary protein.

\section{Efflux studies}

Capillaries were incubated with ${ }^{86} \mathrm{Rb}$ for $2 \mathrm{~h}$ until ${ }^{86} \mathrm{Rb}$ uptake achieved equilibrium (Chaplin et al., 1981). The capillaries were briefly centrifuged in a microcentrifuge, the ${ }^{86} \mathrm{Rb}$-containing supernatant was discarded, and the capillaries were resuspended in $1 \mathrm{ml}$ of PBS alone or PBS containing $1 \mathrm{~m} M$ hypoxanthine and $0.1 \mathrm{U} / \mathrm{ml}$ of xanthine oxidase. Aliquots of $0.2 \mathrm{ml}$ were sampled at $0,10,20$. and $30 \mathrm{~min}$. The rubidium content remaining within the cells was determined by filtration and washing with iced buffered saline as in the uptake studies.

\section{Statistical analysis}

All conditions were examined in triplicate. Individual results were compared to control using a one-tailed $t$ test for paired samples.

\section{RESULTS}

Free radicals generated by xanthine oxidase and hypoxanthine or acetaldehyde inhibited ${ }^{86} \mathrm{Rb}$ uptake. This inhibition progressed over $20 \mathrm{~min}$ in a dose-related fashion with an increase in xanthine oxidase concentration (Fig. 1). There was no effect on rubidium uptake at xanthine oxidase concentrations ranging from $0.001 \mathrm{U} / \mathrm{ml}$ to $0.01 \mathrm{U} / \mathrm{ml}$, but a gradual reduction in ouabain-sensitive uptake occurred at an enzyme concentration of $0.03-0.1 \mathrm{U} /$ $\mathrm{ml}$. Therefore, a concentration of $0.1 \mathrm{U} / \mathrm{ml}$ of xanthine oxidase was chosen for subsequent experiments. There was no effect of free radicals on ${ }^{86} \mathrm{Rb}$ uptake in the presence of ouabain. In mammalian cells, ${ }^{86} \mathrm{Rb}$ is transported in essentially the same manner as potassium (Vaughn and Cook, 1972). Since ouabain-sensitive potassium transport is mediated by $\mathrm{Na}^{+}, \mathrm{K}^{+}$-ATPase (Akera et al., 1969) ouabain-sensitive ${ }^{86} \mathrm{Rb}$ uptake can be used as a measure of $\mathrm{Na}^{+}, \mathrm{K}^{+}$-ATPase activity. Thus, the free radical reduction of brain capillary ${ }^{86} \mathrm{Rb}$ uptake appears due to inhibition of $\mathrm{Na}^{+}, \mathrm{K}^{+}$-ATPase activity. When acetaldehyde alone was added to the capillaries,

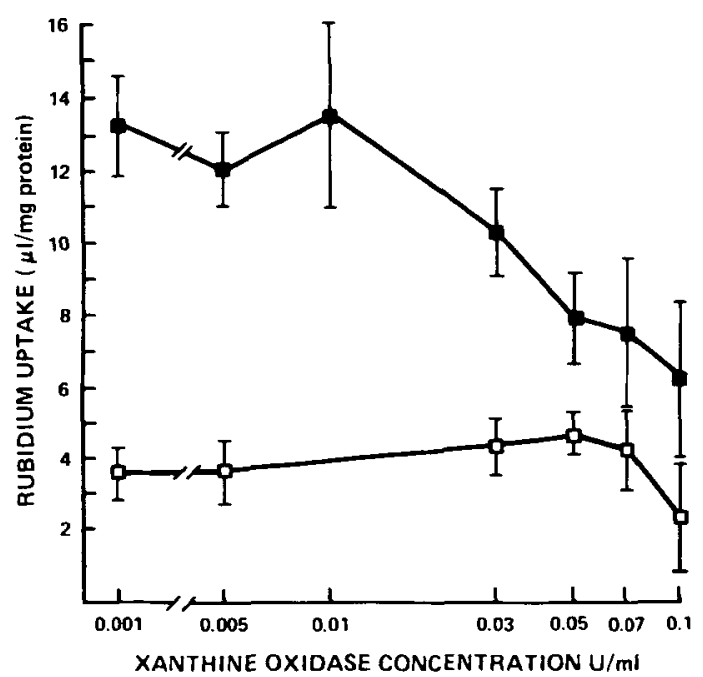

FIG. 1. Effect of increasing concentration of xanthine oxidase generated free radicals on total ${ }^{86} \mathrm{Rb}$ uptake. The upper curve $(\square)$ represents uptake with increasing xanthine oxidase concentration; the lower curve $(\square)$ represents uptake under the same conditions together with $5 \mathrm{mM}$ ouabain. All samples contained $10 \mathrm{mM}$ acetaldehyde and xanthine oxidase at concentrations of $\mathrm{U} / \mathrm{ml}$ as shown, and were incubated for $1 \mathrm{~h}$ prior to examination of ${ }^{86} \mathrm{Rb}$ uptake over 20 $\min$ at $37^{\circ} \mathrm{C}$. 
TABLE 1. Brain capillary rubidium uptake

\begin{tabular}{lc}
\hline \multicolumn{1}{c}{ Conditions } & $\begin{array}{c}\text { Rubidium uptake } \\
(\mu \mathrm{l} / \mathrm{mg} \text { protein/20 min) }\end{array}$ \\
\hline $\begin{array}{l}\text { Control (PBS buffer) } \\
\text { Acetaldehyde }(10 \mathrm{~m} M)\end{array}$ & $8.5 \pm 2.1$ \\
$\begin{array}{c}\text { Acetaldehyde }(10 \mathrm{~m} M)+ \\
\quad \text { xanthine oxidase }(0.1 \mathrm{U} / \mathrm{ml})\end{array}$ & $2.6 \pm 1.8$ \\
$\begin{array}{c}\text { Acetaldehyde }(10 \mathrm{~m} M)+ \\
\text { xanthine oxidase }(0.1 \mathrm{U} / \mathrm{ml})+ \\
\text { allopurinol }(3 \mathrm{mM})\end{array}$ & $7.9 \pm 1.3^{a}$ \\
\hline
\end{tabular}

A $0.2-\mathrm{ml}$ suspension of capillaries was preincubated in buffer containing the reagents listed above, for $2 \mathrm{~h}$ at $37^{\circ} \mathrm{C}$. Capillary ${ }^{86} \mathrm{Rb}$ uptake over $20 \mathrm{~min}$ at $37^{\circ} \mathrm{C}$ was then measured as described. Results are the means \pm SD of three determinations. In separate experiments xanthine oxidase alone at $0.1 \mathrm{U} / \mathrm{ml}$ had no effect on $\mathrm{Rb}$ uptake over $20 \mathrm{~min}$ incubation time.

${ }^{a} \mathrm{p}<0.01$ when compared to control.

${ }^{86} \mathrm{Rb}$ uptake was unchanged (Table 1). The addition of allopurinol, a specific inhibitor of xanthine oxidase, prevented inhibition of rubidium uptake (Table 1). These results indicate that the inhibition of rubidium uptake was caused by xanthine oxidase generated free radicals and not by nonspecific effects of the free radical generating system.

If ${ }^{86} \mathrm{Rb}$ uptake in the presence of free radicals is reduced because $\mathrm{Na}^{+}, \mathrm{K}^{+}$-ATPase is inhibited, then the extracellular/intracellular $\mathrm{Na}^{+}$gradient should decrease. Small neutral amino acid transport as measured by $\left[{ }^{14} \mathrm{C}\right]$ meAIB uptake is dependent on the $\mathrm{Na}^{+}$gradient (Betz and Goldstein, 1978), and therefore, $\left[{ }^{14} \mathrm{C}\right] \mathrm{meAIB}$ accumulation by brain capillaries serves as an indirect measure of the sodium gradient. As shown in Table $2,\left[{ }^{14} \mathrm{C}\right]$ meAIB uptake

TABLE 2. Capillary uptake of meAIB and 3-O-MG

\begin{tabular}{lrcc}
\hline & \multicolumn{3}{c}{$\begin{array}{c}\text { Capillary uptake } \\
(\mu \mathrm{l} / \mathrm{mg} \text { protein/time })\end{array}$} \\
\cline { 2 - 4 } & Control & Ouabain & $\begin{array}{c}\text { Xanthine } \\
\text { oxidase }\end{array}$ \\
\hline meAlB (60 min) & $11.2 \pm 3.4$ & $1.3 \pm 0.6^{a}$ & $1.8 \pm 1.0^{b}$ \\
3- $O$-MG (30 s) & $2.0 \pm 0.4$ & - & $1.5 \pm 0.5$ \\
3-O-MG (10 min) & $2.2 \pm 0.7$ & - & $1.9 \pm 0.5$ \\
\hline
\end{tabular}

$\left[{ }^{14} \mathrm{C}\right]$ me AIB uptake was measured in medium containing $1 \mathrm{mM}$ hypoxanthine. Where indicated the concentration of ouabain was $5 \mathrm{mM}$ and that of xanthine oxidase $0.1 \mathrm{U} / \mathrm{ml}$. A $0.2-\mathrm{ml}$ suspension of capillaries was preincubated at $37^{\circ} \mathrm{C}$ for $30 \mathrm{~min}$ with these compounds, then $0.05 \mathrm{ml}$ of $\left[{ }^{14} \mathrm{C}\right] \mathrm{me} A I B$ in PBS was added, and the suspension incubated at $37^{\circ} \mathrm{C}$ for $60 \mathrm{~min} .\left[{ }^{3} \mathrm{H}\right] 3$ $O$-MG uptake was measured by incubating a $0.2-\mathrm{ml}$ suspension of capillaries for $30 \mathrm{~min}$ at $37^{\circ} \mathrm{C}$ in medium containing $1 \mathrm{mM}$ hypoxanthine either in the absence or presence of $0.1 \mathrm{U} / \mathrm{ml}$ of xanthine oxidase. $\left[{ }^{3} \mathrm{H}\right] 3-O-M G$ in $0.05 \mathrm{ml}$ of PBS was added and incubation continued at $37^{\circ} \mathrm{C}$. Uptake was measured over $30 \mathrm{~s}$ for transport studies, and equilibrium distribution of cell water, using $\left[{ }^{3} \mathrm{H}\right]$ 3-O-MG as a marker, was measured over $10 \mathrm{~min}$. Results are the means \pm SD of three determinations.

${ }^{a} \mathrm{p}<0.005$ compared to control.

${ }^{b} \mathrm{p}<0.02$ compared to control. by isolated brain capillaries was reduced by preincubation with a free radical producing system. This suggests that the $\mathrm{Na}^{+}$gradient was reduced, consistent with the free radical inhibitory effect on ${ }^{86} \mathrm{Rb}$ uptake. As a reduction in ${ }^{86} \mathrm{Rb}$ uptake might reflect either nonspecific inhibition of all transport sytems or an enhanced efflux of ${ }^{86} \mathrm{Rb}$, it was necessary to determine if other transport systems were affected and if cell membrane integrity was damaged. Neither the facilitated transport system for glucose (Table 2), the capillary water space (Betz et al., 1979) (Table 2), nor the rate of ${ }^{86} \mathrm{Rb}$ efflux from capillaries (Fig. 2) was altered by incubating with free radicals. Therefore, reduced ouabain-sensitive ${ }^{86} \mathrm{Rb}$ uptake indicates some specificity of free radicals for the $\mathrm{Na}^{+}, \mathrm{K}^{+}$-ATPase.

Since the superoxide anion produced by xanthine oxidase is converted to hydrogen peroxide and other radical species in biologic systems (Del Maestro, 1980), we used radical scavengers to determine which species inhibited transport. Catalase catalyzes the conversion of hydrogen peroxide to water and oxygen. The addition of catalase almost completely blocked the inhibition of ${ }^{86} \mathrm{Rb}$ uptake (Table 3). Superoxide dismutase, which decomposes superoxide to hydrogen peroxide and oxygen, was without effect (data not shown). Ethanol and mannitol, which should quench the hydroxyl radical (Dorfman and Adams, 1964), had no effect; neither did deferoxamine, which should inhibit ironcatalyzed formation of the hydroxyl and singlet oxygen radicals (Butler and Halliwell, 1982). Hydrogen peroxide at a concentration of $1 \mathrm{mM}$ did not inhibit ${ }^{86} \mathrm{Rb}$ uptake (data not shown).

From these results it is unclear which free radical inhibited ${ }^{86} \mathrm{Rb}$ uptake although it appears to be a species related to hydrogen peroxide. The inconsistent pattern of protection by free radical scavengers is similar to the variable effect of scavengers evi-

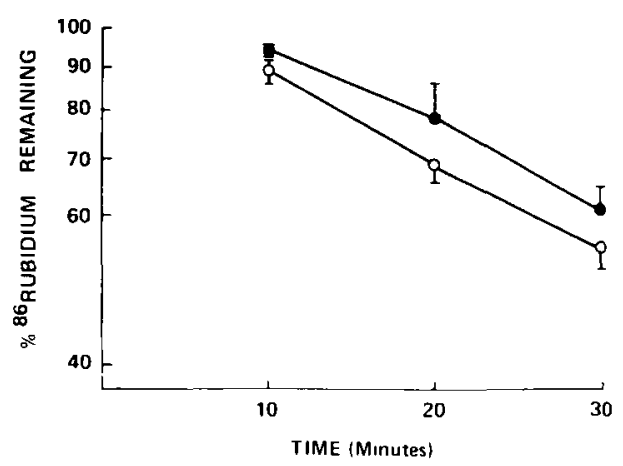

FIG. 2. Efflux of ${ }^{86} \mathrm{Rb}$ from capillaries in the presence of free radicals. Isolated capillaries were loaded with ${ }^{86} \mathrm{Rb}$ by incubation for $2 \mathrm{~h}$ at $37^{\circ} \mathrm{C}$ in media containing $1 \mathrm{mM}$ hypoxanthine and $20 \mathrm{mCi} / \mathrm{ml}$ of ${ }^{86} \mathrm{Rb}$. After rapid washing to remove extracellular ${ }^{86} \mathrm{Rb}$, efflux at $37^{\circ} \mathrm{C}$ was studied either in the presence $(O)$ or absence $(O)$ of $0.1 \mathrm{U} / \mathrm{ml}$ of xanthine oxidase. 
TABLE 3. Capillary uptake of ${ }^{86} R b$ in the presence of free radical scavengers

\begin{tabular}{lc}
\hline \multicolumn{1}{c}{ Condition } & $\begin{array}{c}\text { Rubidium uptake } \\
(\mu \mathrm{l} / \mathrm{mg} \text { protein/20 min })\end{array}$ \\
\hline Control buffer & $7.3 \pm 1.7$ \\
Xanthine oxidase, $0.1 \mathrm{U} / \mathrm{ml}$ & $1.9 \pm 0.7^{a}$ \\
$\mathrm{XO}+$ catalase, $10 \mu \mathrm{g} / \mathrm{ml}$ & $6.1 \pm 1.4$ \\
$\mathrm{XO}+$ ethanol $1 \%(\mathrm{vol} / \mathrm{vol})$ & $2.0 \pm 0.7^{a}$ \\
XO + mannitol, $50 \mathrm{mM}$ & $2.6 \pm 1.1^{b}$ \\
XO + deferoxamine mesylate, & \\
$10 \mu \mathrm{g} / \mathrm{ml}$ & $2.6 \pm 0.9^{b}$ \\
\hline
\end{tabular}

Suspending buffer contained $10 \mathrm{mM}$ acetaldehyde and additional reagents as listed above. A $0.2-\mathrm{ml}$ suspension of capillaries was preincubated for $2 \mathrm{~h}$ at $37^{\circ} \mathrm{C}$. ${ }^{86} \mathrm{Rb}$ uptake over $20 \mathrm{~min}$ at $37^{\circ} \mathrm{C}$ was then measured as described. Results are the means \pm SD of three determinations. Superoxide dismutase at $50 \mu \mathrm{g} / \mathrm{ml}$ had no protective effect (data not shown). XO, Xanthine oxidase, $0.1 \mathrm{U} / \mathrm{ml}$.

${ }^{a} \mathrm{p}<0.005$ compared to control

${ }^{b} \mathbf{p}<0.01$ compared to control.

dent in other systems (Kellogg and Fridovich, 1977; Lynch and Fridovich, 1978; Del Maestro et al., 1980, 1981; Kono and Fridovich, 1982; Chan et al., 1982).

\section{DISCUSSION}

Brain edema is a prominent feature in cerebral ischemic injury (Adams and Victor, 1982). Since brain capillaries perform an important role in brain ion homeostasis, we examined whether free radical injury of the capillaries can be implicated in the formation of postischemic cytotoxic cerebral edema.

Our results show that when isolated brain capillaries are incubated with a free radical producing system, uptake of ${ }^{86} \mathrm{Rb}$ is inhibited. This effect appears to be the result of inhibition of $\mathrm{Na}^{+}, \mathrm{K}^{+}$ATPase activity and not of a generalized reduction of cell membrane integrity or transport systems. The mechanism of free radical inhibition remains uncertain. One may speculate that free radicals attack double bonds in the lipid components of the membrane bilayer (Demopoulos et al., 1980). Altering the double bond would alter the structure of the lipid, thus affecting membrane bilayer fluidity and potentially affecting $\mathrm{Na}^{+}, \mathrm{K}^{+}$-ATPase function. Alternatively, free radicals could attack the protein structure of the $\mathrm{Na}^{+}, \mathrm{K}^{+}$-ATPase, resulting in alteration of transport. Finally free radicals might adversely affect energy metabolism of the cells which would cause a secondary decrease in $\mathrm{Na}^{+}, \mathrm{K}^{+}$ATPase activity.

Other studies confirm that $\mathrm{Na}^{+}, \mathrm{K}^{+}$-ATPase is susceptible to attack by free radicals. Whole brain $\mathrm{Na}^{+}, \mathrm{K}^{+}$-ATPase activity was reduced following exposure to xanthine oxidase and xanthine similar to the system used in the experiements reported here (Hexum and Fried, 1979). In another study, incu- bation of bovine lenses in micromolar concentrations of hydrogen peroxide inhibited ${ }^{86} \mathrm{Rb}$ uptake without increasing membrane permeability (Garner et al., 1983). These same investigators observed that incubation of purified bovine lens or bovine kidney $\mathrm{Na}^{+}, \mathrm{K}^{+}$-ATPase with $1 \mathrm{~m} M$ hydrogen peroxide altered the kinetic properties of the enzyme (Garner et al., 1984).

There is also evidence to suggest that $\mathrm{Na}^{+}, \mathrm{K}^{+}$ATPase in brain may be unusually sensitive to the effects of reperfusion injury. Although whole brain $\mathrm{Na}^{+}, \mathrm{K}^{+}$-ATPase was unaffected by up to $6 \mathrm{~h}$ of ischemia in the gerbil, on reperfusion, $\mathrm{Na}^{+}, \mathrm{K}^{+}$ATPase declined to $42 \%$ of control and remained reduced for $5 \mathrm{~h}$ (Schwartz et al., 1976). In another study, $\mathrm{Na}^{+}, \mathrm{K}^{+}$-ATPase activity was inhibited during ischemia and recovered only after $1 \mathrm{~h}$ of reperfusion (Enseleit et al., 1984). Since it appears likely that free radicals are produced during ischemia and reperfusion (Yamamoto et al., 1983; Watson et al., 1984), our results suggest that these reactive species may be responsible for the observed decrease in $\mathrm{Na}^{+}, \mathrm{K}^{+}$-ATPase activity.

Taking all of these observations into consideration, a possible mechanism for the production of postischemic cerebral edema can be hypothesized. Following cerebral ischemia, brain tissue levels of hypoxanthine increase due to the breakdown of adenosine to hypoxanthine (Berne et al., 1974; Kleihues et al., 1974). During reperfusion, hypoxanthine from other regions may be transported to the brain capillary endothelial cells. These cells were recently shown to contain xanthine oxidase (Betz, 1985 ), which could produce free radicals on exposure to hypoxanthine. The free radicals produced by endothelial cells could then attack $\mathrm{Na}^{+}, \mathrm{K}^{+}$. ATPase, thereby impairing ion homeostasis in the brain capillary. We speculate that such damage could exacerbate the biochemical changes observed in cytotoxic brain edema.

Acknowledgment: We thank Mr. Otho Artis, Jr. and Mr. Peter Thomas for their technical assistance and Mrs. Joy Shulke, Mrs. Sandra Tucker, and Ms. Wendi McKay for assistance in preparing the manuscript. We thank Dr. Gary W. Goldstein for kindly reviewing the manuscript. This work was supported by a grant-in-aid from the American Heart Association through funds contributed in part by the Michigan affiliate. W.D.L. was supported by a NIH fellowship (NS07222). A.L.B. is an Established Investigator of the American Heart Association.

\section{REFERENCES}

Adams R. D. and Victor M. (1982) Principles of Neurology, 2nd edit. McGraw-Hill, New York.

Adams G. E. and Wardman P. (1977) Free radicals in biology: the pulse radiolysis approach, in Free Radicals in Biology. Vol. 3 (Pryor W. A. ed), pp. 53-96. Azademic Press, New York. 
Akera T., Larsen F. S., and Brody T. M. (1979) The effect of ouabain on sodium- and potassium-activated adenosine triphosphatase from the hearts of several mammalian species. J. Pharmacol. Exp. Ther. 170, 17-26.

Berne R. M., Rubio R., and Curnish R. R. (1974) Release of adenosine from ischemic brain. Effect on cerebral vascular resistance and incorporation into cerebral adenine nucleotides. Circ. Res. 35, 262-271.

Betz A. L. (1983) Sodium transport in capillaries isolated from rat brain. $J$. Neurochem. 41, 1150-1157.

Betz A. L. (1985) Identification of hypoxanthine transport and xanthine oxidase activity in brain capillaries. J. Neurochem. 44, 574-579.

Betz A. L. and Goldstein G. W. (1978) Polarity of the bloodbrain barrier: neutral amino acid transport into isolated brain capillaries. Science 202, 225-227.

Betz A. L., Csejtey J., and Goldstein G. W. (1979) Hexose transport and phosphorylation by capillaries isolated from rat brain. Am. J. Physiol. 236, C96-C102.

Bradbury M. (1979) The Concept of a Blood-Brain Barrier, pp. 214-259. John Wiley, New York.

Butler J. and Halliwell B. (1982) Reaction of iron-EDTA chelates with the superoxide radicals. Arch. Biochem. Biophys. 218, 174-178.

Chan P. H., Yurko M., and Fishman R. A. (1982) Phospholipid degradation and cellular edema induced by free radicals in brain cortical slices. J. Neurochem. 38, 525-531.

Chan P. H., Fishman R. A., Caronna J., Schmidley J. W. Prioleau G., and Lee J. (1983) Induction of brain edema following intracerebral injection of arachidonic acid. Ann. Neurol. 13, 625-632.

Chan P. H., Schmidley J. W., Fishman R. A., and Conyar S. M. (1984) Brain injury, edema and vascular permeability changes induced by oxygen-derived free radicals. Neurology 34, 315-320.

Chaplin E. R., Free R. G., and Goldstein G. W. (1981) Inhibition by steroids of the uptake of potassium by capillaries isolated from rat brain. Biochem. Pharmacol. 30, 241-245.

Del Maestro R. F. (1980) An approach to free radicals in medicine and biology. Acta Physiol. Scand. (Suppl.) 492, 153168.

Del Maestro R. F., Thaw H. H., Bjork J., Planker M., and Arfors K. E. (1980) Free radicals as mediators of tissue injury. Acta Physiol. Scand. (Suppl.) 492, 43-57.

Del Maestro R. F., Bjork J., and Arfors K. E. (1981) Increase in microvascular permeability induced by enzymatically generated free radicals. Microvasc. Res. 22, 255-270.

Demopoulos H. B., Flamm E. S., Pietronigro D. D., and Seligman M. L. (1980) The free radical pathology and the microcirculation in the major central nervous system disorders. Acta Physiol. Scand. (Suppl.) 492, 91-119.

Dorfman L. M. and Adams G. E. (1964) Reactivity of Hydroxyl Radical in Aqueous Solutions. NSRDS-NBS, No. 46 ,
United States Dept. Commerce, National Bureau of Standards, Washington, D.C.

Enseleit W. H., Domer F. R., Jarrott D. M., and Baricos W. H. (1984) Cerebral phospholipid content and $\mathrm{Na}^{+}, \mathrm{K}^{+}$-ATPase activity during ischemia and postischemic reperfusion in the Mongolian gerbil. J. Neurochem. 43, 320-327.

Fridovich I. (1978) The biology of oxygen radicals. Science 201, 875-880.

Garner W. H., Garner M. H., and Spector A. (1983) $\mathrm{H}_{2} \mathrm{O}_{2}$-induced uncoupling of bovine lens $\mathrm{Na}^{+}, \mathrm{K}^{+}$-ATPase. Proc. Natl. Acad. Sci. USA 80, 2044-2048.

Garner M. H., Garner W. H., and Spector A. (1984) Kinetic cooperativity change after $\mathrm{H}_{2} \mathrm{O}_{2}$ modification of $(\mathrm{Na}, \mathrm{K})$ ATPase. J. Biol. Chem. 259, 7712-7718.

Goldstein G. W. and Betz A. L. (1983) Recent advances in understanding brain capillary function. Ann. Neurol. 14, 389395.

Hexum T. D. and Fried R. (1979) Effects of superoxide and radicals on transport $(\mathrm{Na}+\mathrm{K})$ adenosine triphosphatase and protection by superoxide dismutase. Neurochem. Res. 4, 73-82.

Kellogg E. W. and Fridovich I. (1977) Liposome oxidation and erythrocyte lysis by enzymatically generated superoxide and hydrogen peroxide. J. Biol. Chem. 252, 6721-6728.

Kleihues P., Kobayashi K., and Hossmann K.-A. (1974) Purine nucleotide metabolism in the cat brain after one hour of complete ischemia. $J$. Neurochem. 23, 417-425.

Kono Y. and Fridovich I. (1982) Superoxide radical inhibits catalase. J. Biol. Chem. 257, 5751-5754.

Lynch R. E. and Fridovich I. (1978) Effects of superoxide on the erythrocyte membrane. J. Biol. Chem. 253, 1838-1845.

Miquel J., Oro J., Bensch K. G., and Johnson J. E. (1977) Lipofuscin: fine structural and biochemical studies, in Free Radicals in Biology, Vol. 3 (Pryor W. A., ed), pp. 133-182. Academic Press, New York.

Schwartz J. P., Mrsulja B. B., Mrsulja B. J., Passonneau J. V., and Klatzo I. (1976) Alterations of cyclic nucleotide-related enzymes and ATPase during unilateral ischemia and recirculation in gerbil cerebral cortex. J. Neurochem. 27, 101107.

Vaughn G. L. and Cook J. S. (1972) Regeneration of cationtransport capacity in Hela cell membranes after specific blockade by ouabain. Proc. Natl. Acad. Sci. USA 69, 26272631.

Watson B. D., Busto R., Goldberg W. J., Santiso M., Yoshida S., and Ginsberg M. D. (1984) Lipid peroxidation in vivo induced by reversible global ischemia in rat brain. $J$. Neurochem. 42, 268-274.

Yamamoto M., Shima T., Uozomi T., Sogabe T., Yamada K. and Kawasaki T. (1983) A possible role of lipid peroxidation in cellular damages caused by cerebral ischemia and the protective effect of $\alpha$-tocopheral administration. Stroke 14, 977-982. 